\title{
Children's Participation in Library Space Improvement Programme
}

\author{
Paramita Atmodiwirjo, Yandi Andri Yatmo \\ Department of Architecture \\ Universitas Indonesia \\ mitayandi@gmail.com
}

\begin{abstract}
This paper illustrates a physical improvement programme in a primary school library through a participatory process involving children in designing and renovating the space. The improvement of library space has contributed positively in promoting children's active use of the library space. The involvement of children in the process has also promoted their positive attitude and sense of belonging toward the space. Commitment building of the whole school community becomes a challenge during the process and beyond. Promoting children's active role in the development, management and maintenance of the space becomes important to ensure sustainability after the programme.
\end{abstract}

Keywords: Children, participation, library, space.

eISSN 2514-751X@ 2017 The Authors. Published for AMER ABRA by e-International Publishing House, Ltd., UK. This is an open access article under the CC BY-NC-ND license (http://creativecommons.org/licenses/by-nc$n d / 4.0)$. Peer-review under responsibility of AMER (Association of Malaysian Environment-Behaviour Researchers), ABRA (Association of Behavioural Researchers on Asians) and $c E-B s$ (Centre for EnvironmentBehaviour Studies), Faculty of Architecture, Planning \& Surveying, Universiti Teknologi MARA, Malaysia.

https://doi.org/10.21834/aje-bs.v2i4.207 


\subsection{Introduction}

Quality of educational facilities is important in order to improve the quality of education. School library becomes an important facility required to support the earning process. It becomes an integral part of the educational process (IFLA/ UNESCO, 1999). A good school library is characterised by sufficient space with good quality, equipped with sufficient collection with good management system to ensure optimum utilisation by the school community. Unfortunately, in general the quality of libraries in the majority of schools in Indonesia, especially in primary schools, is still far from satisfactory. Limited collection, lack of library space and facilities become critical problems in school libraries (Perpustakaan Nasional RI, 2001). In general, the current condition of school libraries, especially those in state schools, could not adequately support the promotion of literacy activities among the children. Various efforts have been made by national and local governments in renovating school spaces, including the libraries, and to provide more library collections. However, with over 140,000 schools throughout the country (Ministry of National Education, 2009), there are still a large number of school libraries that require attention for development.

Nevertheless, the development of a quality school library does not merely depend on the improvement of physical space, facilities and collections. Beyond those physical aspects, there is a more critical issue of developing positive attitudes of the whole school community toward the library as a center of literacy activities in schools. Our observations in various primary schools suggest that libraries have not been considered as important hubs for activities in many schools.

At the moment the development of school libraries tend to adopt a top-down approach, which rarely involves the school community as the main agent of change. Such an approach seems to fail to locate the libraries as the heart of the schools and as the centre of children's everyday activities. In order to put libraries back to their place as the heart of the schools, there is a need to revisit the approach in developing school libraries. This paper illustrates a physical improvement programme in a primary school library in Indonesia involving children in designing and renovating the space. The programme becomes a case to examine the extent to which such a participatory process may contribute positively to the utilisation of the school library by the school community.

\subsection{The Needs For Participatory Approach}

Good library space is one of the important aspects that need to be considered in promoting library utilisation. School libraries with good design may encourage the school community to spend more time in the library (IFLA/UNESCO, 2002). Studies have suggested that in general the improvement of physical environment of libraries is correlated significantly with the increase in the utilisation of libraries. With the new designs, a library could be more attractive and could become the heart of the community, as indicated by the increasing number of visits to library and the increasing number of library loans (The Commission for Architecture and the Built Environment, 2003). 
The efforts to promote the quality improvement of the school library should also take into account the potential role of the school community. It is recommended that the development of school library is based on 'a whole school approach' (The Library Association, 2002). Based on this approach, the planning of the library should reflect the profile of the teachers and pupils, while also becoming the part of the school policies. It becomes important to involve children, teachers and other related parties in the process of library planning, development, utilisation and management.

The attempt to involve children in the process of library improvement requires an understanding that children should not be seen as the passive users of the environment. In fact, they are capable of becoming active agents of change for their own environment. Children have capabilities to develop design ideas, especially for their everyday environment (Francis \& Lorenzo, 2006). This has been demonstrated in various cases of space improvement with the participation of children and young people (Brink \& Yost, 2004; Parnell, 2004; Yanagisawa, 2007 and many more). Participation of children and young people in the space improvement activities has promoted their sense of belonging towards the space (Nunan, 1997).

Particularly the process can also be seen as a way to promote children competence in experiencing, learning, evaluating and taking actions in their own environment. The participatory programs could be designed to enhance children's involvement and responsibility in contributing to a setting (Heft \& Chalwa, 2006). The process of participatory designs also involves social interaction that would promote the expanded horizon of the participants and generate visionary thinking (Sutton \& Kemp, 2006). In this way, the expected outcome of the participatory process is not limited to the physical design ideas, but it may also promote the development of children's competence, attitudes and vision for better future of the space and the society.

An important issue in the development of school library within the context of Indonesian culture is the need to redefine the role of library within the school community. There is a tendency to think that the library is merely a space to keep books, with few attempts to relate it with the learning process of the school (Kariyawan, 2007). This is also further reflected in the current design of most library spaces, which tends to be very formal, furnished with office-like furniture. There have been very few efforts in creating school library space as a place for fun and enjoyment. Ideally, the design of a school library space, furniture and equipments should be "aesthetically appealing to the user and conducive to leisure and learning" (IFLA/UNESCO, 2002). Therefore a school library should not be a place of boredom. However, it is clear that the development of a school library as a conducive environment is much related to the policies and everyday practices of the whole school. Therefore, a key aspect is on developing attitudes of the whole school community towards school library as a centre of activities.

This paper highlights the opportunities of participatory approach to address the challenges in developing attitudes of the school community towards the school library. A programme in the development of a school library in Jakarta, Indonesia becomes an 
exemplary case study to demonstrate the possibilities of participatory methods as a media for promoting literacy activities among the children.

\subsection{Methodology}

\subsection{Action research method}

The study is an action research, which consists of an intervention in a real-world situation and the study of the results of such intervention (Cohen \& Manion, 1994). Action research becomes a method that offers possibility to examine various factors that are involved in the process of intervention as it progresses towards its certain goals (Groat \& Wang, 2002). In this way, action research allows the implementation of an intervention programme that not only benefits the targeted group, but also allows examination of the issues raised during the process and contributes to further development of the intervention program. There are various forms of action research, including education and training, facilitation, advocacy and decision making (Uzzell, 2000). In this study, the action research primarily involved the facilitation of the school community in the improvement of spatial quality of their library. The stages of the research began with the intervention process in the improvement of the school library space through participatory approach, followed by an evaluation to assess the outcome of the process.

\subsection{School library improvement process}

The target of the programme was the library in a state primary school located in South Jakarta. Prior to the programme, the school had a space designated for the library but was not in a proper condition as a library. The space suffered from frequent flood, causing it to be damp and rotten in many parts of the space as well as the damage of the furniture and library collection. Due to such conditions, within the last few years the space was not utilised properly as a school library. However, improvement would be difficult to implement to this space due to its current physical construction. In response to this situation, the school then agreed to allocate another space on the other part of the school building to become the new library space. Although also in a damaged condition, this space was considered as the best alternative to be developed as a school library space.

The improvement work of the library space was conducted through participatory methods, in which the school community, especially the children, were involved in several activities throughout the process. A design workshop was conducted among Year 4 and 5 children to elicit their needs and wants in the library and to develop their creative ideas of library space through the making of three dimensional models. In addition, a simple survey was conducted to collect data from Year 2 and Year 3 children about their favourite colours, activities they expect to do in the library, and their favourite reading collection. The survey was conducted in a fun and interesting way, in which the children expressed their opinion 
by sticking coloured pins on a board of options (Figure 1).

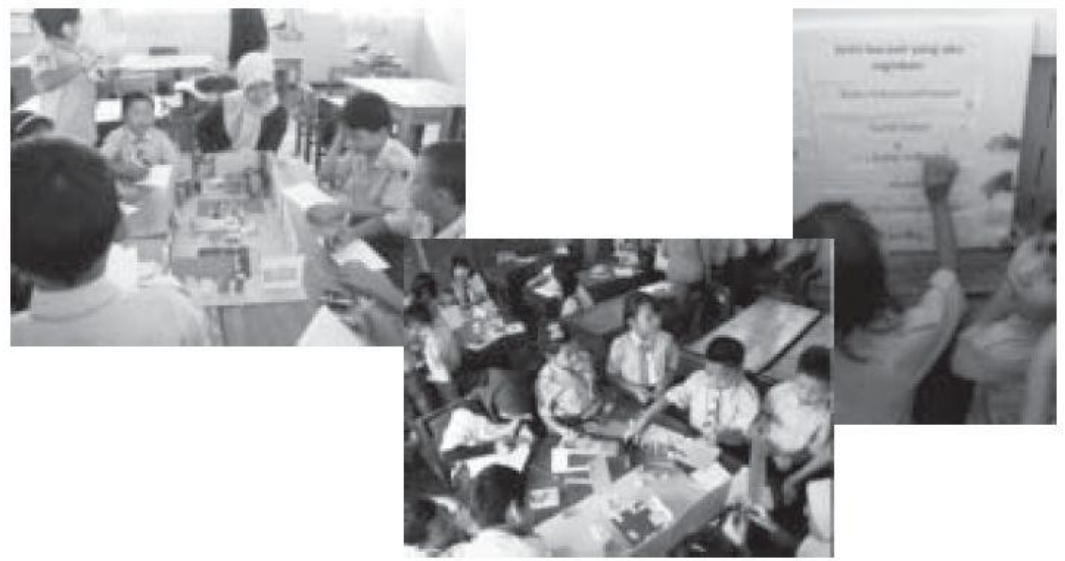

Figure 1: Design workshops and surveys with children
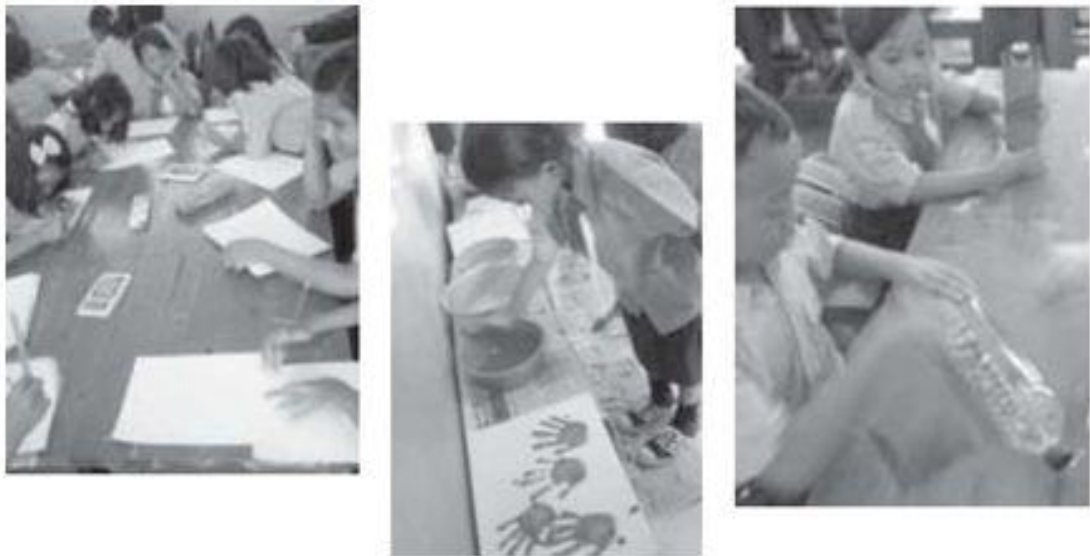

Figure 2: Children create various decorations for the new library space

\subsection{Methods Of Evaluation}

To assess how the library was utilised by the school community after the improvement, a visit was made around two months after the completion of the improvement work. During the visit, the data on the school library utilisation was collected through different methods. A questionnaire was distributed among the children in Year 2-5 (aged around 7-11) to obtain 
data on their utilisation of school library and their opinion about the new library space. There was a total of 111 children who completed the questionnaires. The content of the questionnaires include the questions on the children's everyday use of the library, their opinions towards the new library space, and their feeling on their involvement in the process and their responsibility towards the library. The responses from the children were computed into percentages, illustrating the general pattern on their everyday use of the library and their opinion towards the library and the improvement process.

Along with the distribution of the questionnaire, interviews were conducted with teachers and children assigned as 'junior librarians' in order to obtain description on the school library everyday management and utilisation, as well as problems and issues faced by both teachers and children. In addition, observation was conducted to assess the physical condition of the space and the collection. The record of library visit and lending activities also became the important sources of data on the utilisation of school library. The data obtained through these different methods provide a description on the results of the improvement of the library space as well as the contribution of participatory process on the further utilisation of the school library.

\subsection{Results And Discussions}

\subsection{Utilisation of school library after improvement programme}

The participatory process had transformed the old library space into a new space with better appearance (Figure 3). The library was equipped with basic library collection arranged in a good management system. Soon after the improvement work was completed, the children and teachers immediately utilised the library. Rules on borrowing books and other regulations in the library were socialised among all children at the beginning of the utilisation period. The library opens during school hours, with the children mostly visiting the library during recess period. During lesson hours teachers could also assign the children to go to library, usually as a group to perform some tasks. Children could either read books in the library or bring the books home. Every child visiting the library is recorded in visitor record book, and all children borrowing books were recorded in another record book as well as on inidividual borrower's card stored in the library. Daily management of library loan was carried out by some children assigned as 'junior librarians'.

The utilisation of the school library after the improvement was indicated by the number of children visiting the library and the number of children borrowing books. Based on the children's responses to the questionnaire, $100 \%$ of the children mentioned that they have visited the new library. Based on the record in the visitor book, during the 57 days the library opened, there was a total of 1,262 visits to the library, which was around the average of 22 visits per day. The record of borrowing activities indicated that in each class of Year 1 to Year 6 , there were around 13-22 children that became the library members and actively 
borrowed books. The children in Year 2 and Year 4 were the most active in borrowing books, with the average number of 10.5 and 7.8 books per borrower. The favourite types of collection that the pupils often read or borrowed from the library were storybooks (55\%), magazine or comic $(20.7 \%)$, school subject books (17.1\%), and knowledge/science books $(16.2 \%)$.

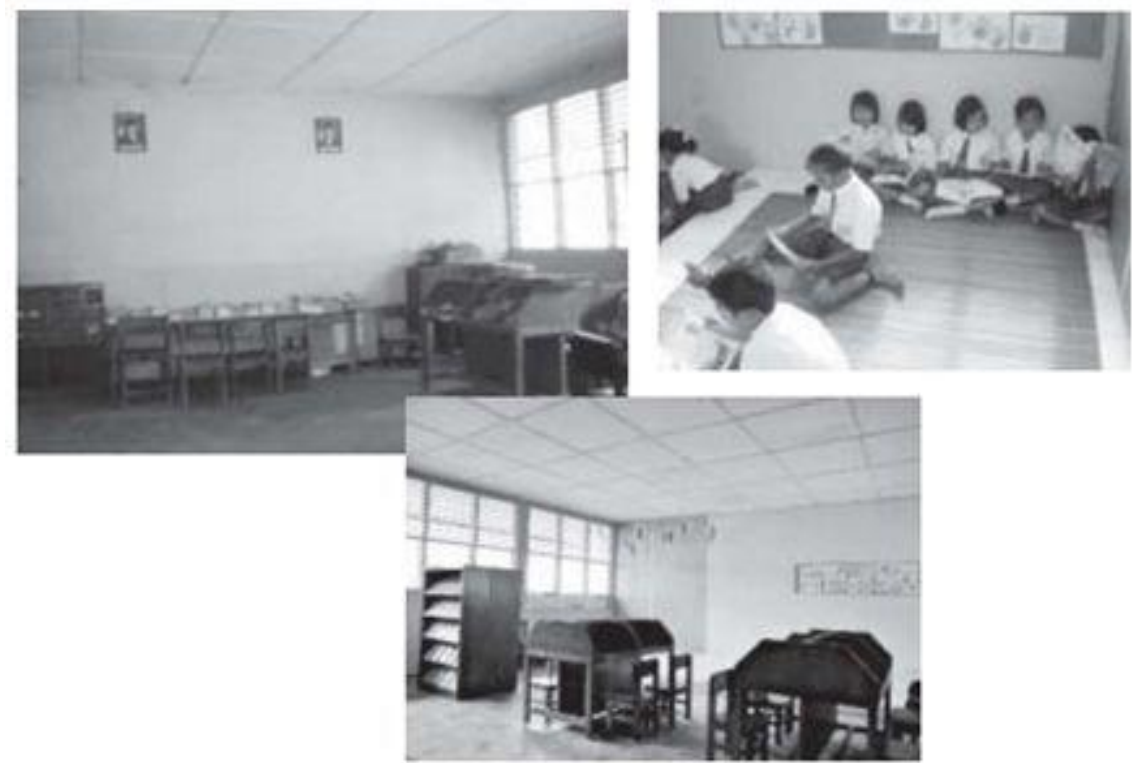

Figure 3: The library space before and after the programme

The children visited the library quite frequently. The majority of the respondents $(61.1 \%)$ mentioned that they visited the library everyday or almost everyday. Other respondents mentioned that they visited the library $2-4$ times a week (19.4\%), once a week $(13.9 \%)$ or only several times a month (3.7\%). The majority of the activities that they mentioned were reading books $(86.5 \%)$ and borrowing books $(80.2 \%)$. Other activities were only mentioned by few pupils, such as doing school works $(6.3 \%)$, sitting $(8.1 \%)$ and having group discussion (4.5\%). The data suggested that the library had performed its function to provide access to various collections well. However, its role as a center of various activities other than reading and borrowing books still needed to be promoted among the children as well as the teachers.

In general, the data above suggests that the children are quite active in utilising the library that have just been improved. The improvement of the library space has enabled them to utilise the library and to obtain access to various library collections. 


\subsection{Improved quality of school library space}

It is also important to know the children's opinion about their new school library space. By understanding the children' perception and feelings about the library space and services, it is possible to get the ideas of aspects that support the utilisation and aspects that require further improvement.

In the questionnaire, the children were asked to mention factors that encouraged and discouraged them to visit the library. They mentioned that they often visited the library because there were lots of books $(78.7 \%)$, because the books were interesting $(16.2 \%)$, because the space was comfortable and good $(11.7 \%)$, because they could do many activities (13.5\%), and because the librarians were nice $(7.2 \%)$. When they were asked the factors that discouraged them to visit library, they mentioned insufficient number of books $(15.3 \%)$, uninteresting books $(12.6 \%)$, unfriendly librarian $(14.4 \%)$, restriction to do many activities $(11.7 \%)$ and uncomfortable spaces $(7.2 \%)$.

Comfortable space seems to become one of the important aspects that can promote the utilisation of library. Almost all the respondents (99.1\%) thought that the library space was comfortable, because of its bright colour (53.2\%), cool temperature (51.4\%), comfortable furniture (19.8\%), decoration (17.1\%) and space for sitting on the floor (18\%). Another important aspect that is important to promote library is the need for a sufficient collection. $62 \%$ of the respondents felt that the current collection is enough, while the other $38 \%$ expected to have more collections. The easiness to browse around the collection also becomes important to consider. The classification system with colour coding seemed to be understood by the majority of respondents $(54.6 \%)$ who mentioned that it was easy to search for the books. Some others mentioned that searching the books was quite difficult (36.1\%) or difficult $(9.3 \%)$.

The utilisation of the library is also related to access. In general, the children felt sufficient access to the library. $46.4 \%$ mentioned that the library always opened all the time, while $48.6 \%$ mentioned that the library usually opened during recess period or after school. Only $5.4 \%$ mentioned that the library were often closed for them.

Overall, the findings from the questionnaire suggested that the improvement work done with the library space had been accepted positively by the children. It showed the potential of the improved library space to encorage children to utilise the library.

\subsection{Children's participation and sense of involvement}

The participatory method that became the major approach in the improvement work of the library space was expected to promote a sense of involvement and belonging among the children towards the library. The data from the questionnaire completed by the children indicated that the majority $(73.9 \%)$ felt thay they had been involved in the improvement process. Only 18\% said that they were not involved and about $7.2 \%$ did not know that the library had been improved. The understanding of the involvement is necessary since it becomes the basis for developing further involvement in the management and utilisation of the library. 
The participation of the children in the library management was also promoted through the assignment of 'junior librarian'. The primary task of the 'junior librarian' was to encourage their peers to visit the library and to assist the teachers in library management. The assignment of the 'junior librarian' was a positive thing, and the children assigned to the task had demonstrated their responsibility. They felt proud of this assignment and their role became very important in the continuation of the library utilisation by the whole school. Unfortunately, some of the other children still tended to think that the task to take care of the library becomes the main responsibility of 'junior librarians' only $(52.3 \%)$ or teachers (14.4\%). There were only $28.8 \%$ who felt that the responsibility should be shared among all children and teachers. It seems that the involvement in the improvement process needs to be followed up by the socisaliation on the role of the whole school in taking care of the library. It is also important that the assignment of 'junior librarian' should involve more children.

In the questionnaire the children were also asked to mention the factors that would make them visit the library more often. Apart from the expectation to have more library collections, some other responses suggested that they would visit the library more often if their friends also went there, or if they were encouraged by the teachers. Such responses indicated the important role of social aspects in library utilisation. Therefore in addition to the physical improvement of library space, it becomes also necessary to promote the visit to library as regular activities of children and teachers.

Another issue found during the evaluation was that the commitment of the teachers in the development of the library still needed to be promoted. As mentioned by the children in the questionnaire, some teachers $(56.8 \%)$ had asked them to go to the library. However, it seemed that not all teachers were encouraged to make library as an integral part of the learning process. The dialog with a teacher that was responsible as the library coordinator also indicated that it was still necessary to socialise the expected role of all teachers in optimising the utilisation of school library. Surprisingly, the children played an important role in encouraging their teachers to provide more access to the library so that they could fulfill their desire to read and borrow books. Their enthusiasm to access information through the library may become a driving factor for the other members of school communities for more intense utilisation and more effective management of the school library.

\subsection{Conclusions}

The development of the school library requires a shifting attitude toward the library - from merely as a place for books to a centre of school community and activities. Participatory process becomes a method to promote involvement of the school community, especially children, in the development, management and utilisation of the school library as the heart of a school.

The case study presented in this paper has illustrated that the improvement programme 
of the school library space has become a positive trigger in promoting active utilization of the library by the school communities. However, the findings of the evaluation also indicated that the process of library space improvement programme needs to embrace various aspects of school library development. The improvement should include not only the physical space, but also the management system and attitude formation of the whole school. The participatory process involving school community, especially children, in planning, design and management of school library has become an approach that develop sense of involvement and belonging towards the library among the children. On the other hand, the process may also pose some challenges in building commitment of the whole school community throughout the process and beyond. There are challenges in involving different actors in the process, sustaining management system, sustaining children's and teacher's interest to the library, and integrating library with the school learning activities. Nevertheless, the improvement of library space has contributed positively and provide opportunities to promote optimum utilisation and to create sense of belonging among the school community. It becomes clear that the physical improvement work may become a generator for starting up the library development; however, it should be developed in parallel with the further improvement on other non-physical aspect.

Promoting children's active role in the development, management and maintenance of the library space becomes important to ensure sustainability after the programme. Children may play many important roles in the attitude formation of the whole school community toward the school library. They may take a role as active users of the library, contribute in the physical improvement work, and get involved in library management activities through assignment as junior librarians. More importantly the children may take a social role in promoting their peers to visit the library and to encourage their teachers to provide more access to the library and to develop an effective library management system. In this way, it becomes important to promote children's active role in the development, management and maintenance of the library space in order to ensure sustainability after the improvement programme.

\section{Acknowledgements}

The school library improvement programme was implemented in several schools in Jakarta and Depok, funded by Community Service Grant (Hibah Pengabdian Masyarakat) Universitas Indonesia 2009 and Joint Research Grant for Government Institution and Higher Education Institution (Hibah Riset Kerjasama Antar Lembaga \& Perguruan Tinggi) 2010. The author would like to thank architecture and library science students from Universitas Indonesia who worked together with the children in the design and improvement works of the library, coordinated by the team leaders Kristanti Dewi Paramita and Diajeng Luki Astria. 
Atmodiwirjo, P., \& Yatmo, Y.A. / Asian Journal of Environmen-Behaviour Studies, ajE-Bs, 2(4) Jul/Sep 2017 (p.21-31)

\section{References}

Brink, L. \& Yost, B. (2004). Transforming Inner-City School Grounds: Lessons from Learning Landscapes. Children, Youth and Environments, 14(1): 208-32.

Cohen, L. \& Manion, L. (1994). Research Methods in Education. London: Routledge.

Francis, M. \& Lorenzo, R. (2006). Children and City Design: Proactive Process and the Renewal' of Childhood. In Spencer, C. \& Blades, M. (Eds.), Children and Their Environments: Learning, Using and Designing Spaces. Cambridge: Cambridge University Press, 217-37.

Heft, H. \& Chalwa, L. (2006). Children as Agents in Sustainable Development: The Ecology of Competence. In Spencer, C. \& Blades, M. (Eds.), Children and Their Environments: Learning, Using and Designing Spaces.

Cambridge: Cambridge University Press, 199-216.

IFLA/UNESCO (1999). IFLA/UNESCO School Library Manifesto. IFLA/UNESCO (2002). The IFLA/UNESCO School Library Guidelines. Groat, L. \& Wang, D. (2002). Architectural Research Methods. New York: John Wiley \& Sons.

Kariyawan, B. (2007). Pemantapan Jaringan Pembinaan Perpustakaan Nasional terhadap Perpustakaan di Lingkungan Sekolah: Pembudayaan Literasi Informasi di Kalangan Siswa. Visi Pustaka, 9(3). Ministry of National Education (2009). Statistik Persekolahan SD 2008/2009.

Nunan, K. (2004). One Small Room. State Library of Queensland. Available from: http:// publib.slq.qld.gov.au/onesmall/ contents.htm, retrieved 10 February 2009.

Parnell, R. (2004). Soundings for Architecture: An Educational Workshop for Adults and Young People. Children, Youth and Environments, 14(2): 229-41.

Perpustakaan Nasional RI (2001). Kajian Perpustakaan Sekolah Dasar Negeri di DKI Jakarta. Jakarta: Perpustakaan Nasional RI.

Sutton, S.E. \& Kemp, S.P. (2006). Young People's Participation in Constructing Socially Just Public Sphere. In Spencer, C. \& Blades, M. (Eds.), Children and Their Environments: Learning, Using and Designing Spaces. Cambridge: Cambridge University Press, 256-276.

The Commission for Architecture and the Built Environment (2004). Involving Young People in the Design and Care of Urban Spaces. London: CABE Space \& CABE Education.

The Library Association (2000). Primary School Library Guidelines. London: The Library Association.

Uzzell, D. (2000). Ethnographic and Action Research. In Breakwell, G. M., Hammond, S. \& Fife-Schaw, C. (Eds.), Research Methods in Psychology. London: Sage, 326-337.

Yanagisawa, K. (2007). School Planning and Design with Children's Participation: A Case Study of Shimoyama Elementary School. Children, Youth and Environments, 17(1): 315-21. 